\title{
Research Paper \\ Role of PASS Cognitive Processes in Explaining the Ability of Word Reading and Text Comprehension in Children with Dyslexia
}

\section{Maryam Samadi ${ }^{1}$, Amir Ghamarani ${ }^{* 2}$, Salar Faramarzi ${ }^{3}$}

1. Ph.D. Student of Psychology and Education of Children with Special Needs, Faculty of Educational Sciences and Psychology, University of Isfahan, Iran

2. Assistant Professor, Department of Psychology and Education of Children with Special Needs, Faculty of Educational Sciences and Psychology, University of Isfahan, Iran

3. Associate Professor, Department of Psychology and Education of Children with Special Needs, Faculty of Educational Sciences and Psychology, University of Isfahan, Iran

Citation: Samadi M, Ghamarani A, Faramarzi S. Role of pass cognitive processes in explaining the ability of word reading and text comprehension in children with dyslexia. Quarterly Journal of Child Mental Health. 2020; 7(2): 268-279.

\section{http://dx.doi.org/10.29252/jcmh.7.2.23}

\section{A R T I C L E I N F O}

Keywords:
Dyslexia,
PASS theory,
reading performance

Received: 24 Jul 2018

Accepted: 3 Jun 2020

Available: 21 Sep 2020

\section{A B S T R A C T}

Background and Purpose: Dyslexia is a neurodevelopmental disorder. Recently, researchers have focused on the cognitive correlates of this disorder. Identifying the cognitive processes of children with dyslexia can provide a deeper understanding of this disorder and guide the effective intervention programs for it. Therefore, the present study aimed to investigate the role of four cognitive processes of Planning, Attention, Simultaneous, and Successive (PASS) in explaining the ability of word reading and text comprehension in children with dyslexia.

Method: This research was a descriptive correlational study. The study population included all the students with dyslexia who were studying at grades two to five of primary school in Isfahan in the academic year of 2017-2018. A sample of 100 students was selected by multistage sampling. Raven's Progressive Matrices (1956), Reading and Dyslexia Test (Karami Noroozi \& Moradi, 2005), Assessment System-second edition (Naglieri, Das \& Goldstein, 2014) were used to collect the data. Data were analyzed by Pearson correlation coefficient and regression analysis.

Results: Findings showed that "word reading" was associated with simultaneous and successive processing and attention, and "text comprehension" was associated with simultaneous and successive processing, planning and attention $(\mathrm{P} \leq 0.01)$. Based on the regression analysis, the simultaneous and successive processing predicts $49 \%$ of the variance of "word reading", whereas successive processing and planning predict $44 \%$ of the variance of "text comprehension".

Conclusion: Results showed that children with dyslexia have dysfunction in simultaneous and successive processing and planning. These finding can be helpful in the process of diagnosing this disorder and designing interventions for it. In fact, identifying the cognitive processes involved in "reading" can provide a deeper understanding of how to facilitate and improve reading performance through explicit training of PASS processes.

\footnotetext{
* Corresponding author: Amir Ghamarani, Assistant Professor, Department of Psychology and Education of Children with Special Needs, Faculty of Educational Sciences and Psychology, University of Isfahan, Iran.

E-mail addresses: A.ghamarani@edu.ui.ac.ir
} 


\section{نقش فرايندهاى شناختى ياس در تبيين توانايى خواندن كلمه و در كى متن در كودكان مبتلا به نارساخوانى}

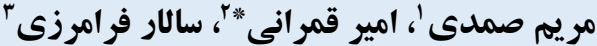

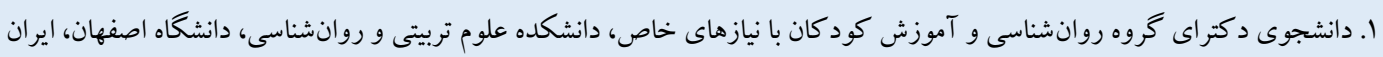

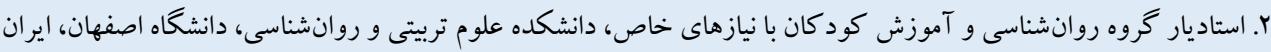

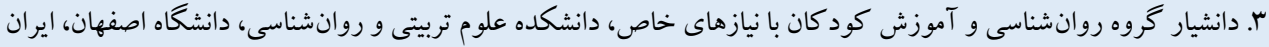

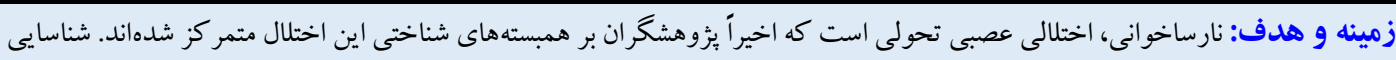

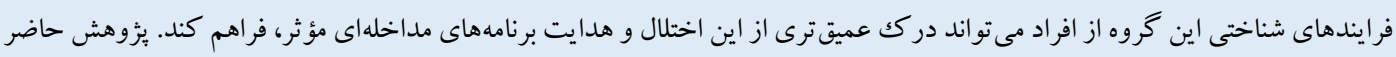

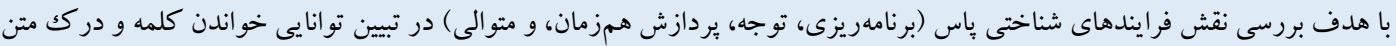
در كود كان مبتلا به نارساخو انى انجام شد.

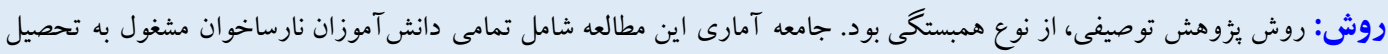

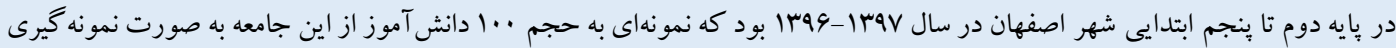

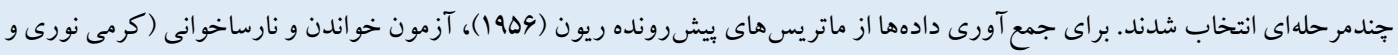

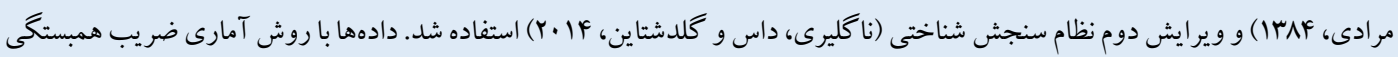
بيرسون و تحليل ركرسيون تجزيه و تحليل شد.

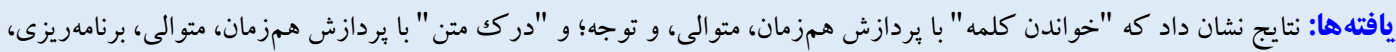

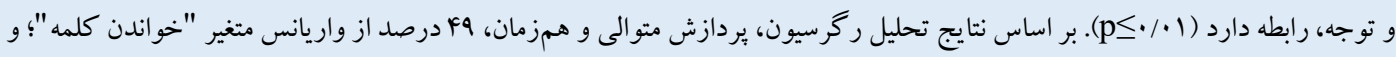

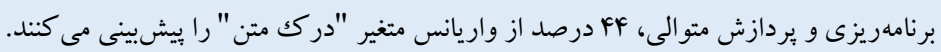

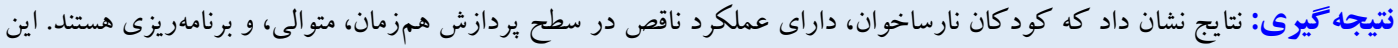

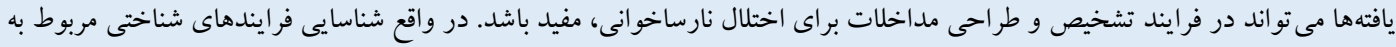

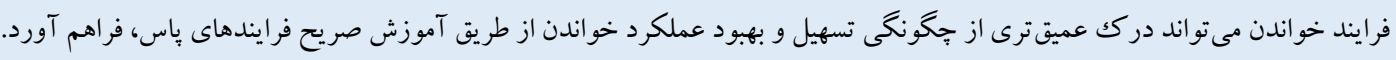

مشخصات مقاله

كليدوازهها:

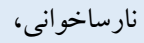

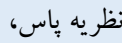
عملكرد خواندن

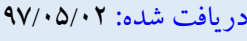

و منتشر شده: 99/4

* نويسنده مسئول: امير قمر انى، استاديار كروه روان شناسى و آموزش كو دكان با نيازهاى خاص، دانشكده علوم تربيتى و روانشناسى، دانشكاه اصفهان، ايران.

رايانه: A.ghamarani@edu.ui.ac.ir 
روى آورد جنـدبعـدى به در كك عميقترى از ماهيت رابطه بين خواندن و شـناخت كمكك مى كند و امكان ارزيابى تشخيصى و مداخله را نيز فراهم

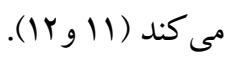

نظريه باس به عنوان يكك نظريه بِردازش شــناختى كه توســـ داس،

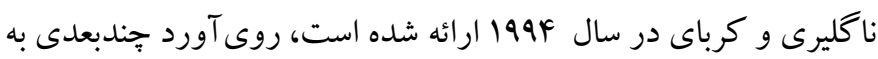
هوش است كه تا حد زيادى مبتنى بر كار عصبروانشناختى لوريا است.

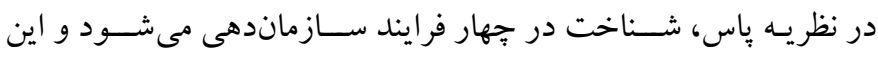

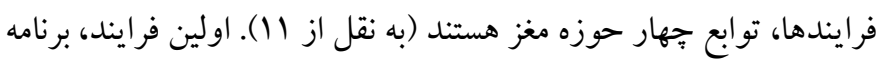

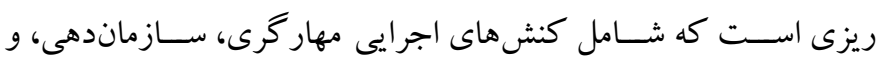

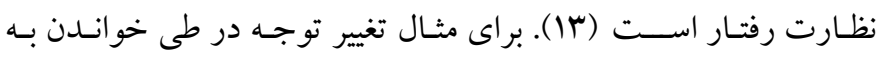
بخشهاى مختلف متن و تخصيص انتخابى منابع به اطلاعات مختلف، در

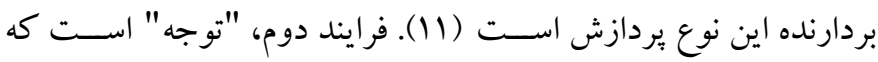

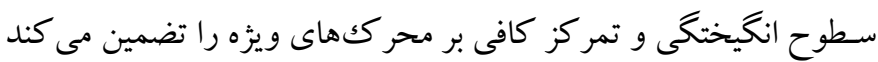

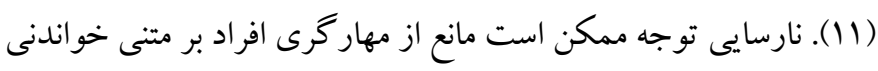

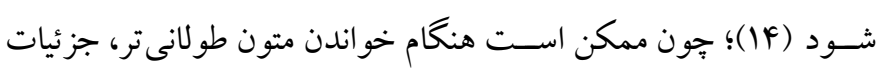
متن حواس آنها را برت كند و در نتيجه نتوانند بر ايدههاى اصلى متمركز

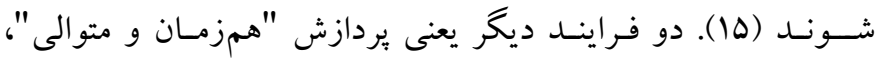
رمز كذارى، تبديل و حفظ اطلاعات را ممكن مى سازند. به موجب فر فر فرايند

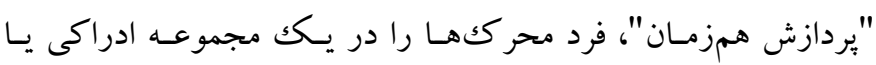

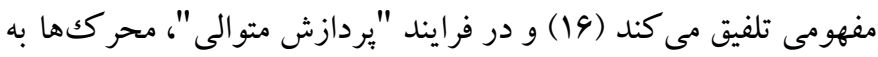

$$
\text { وسيله يك ترتيب خاص تلفيق مى شوند (IV). }
$$

وقتى تكليف يـا رفتـارى نيازمند تلفيق واحدهاى متعدد در يكك كل

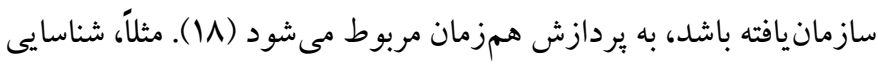

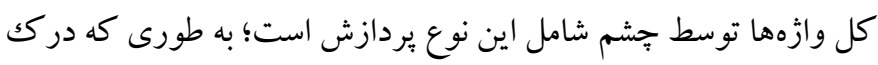

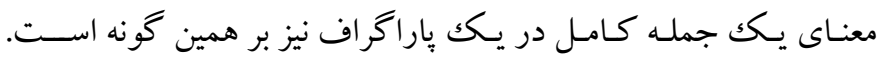

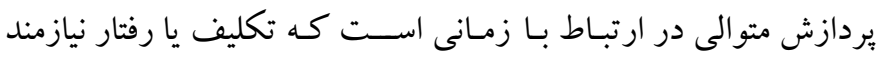

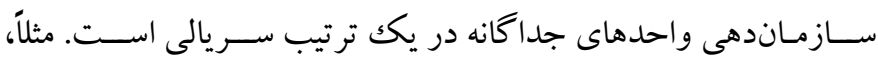

$$
\text { رمز گشايى وازه و هجى (املا) شامل اين نوع بردازش است است دانس (11). }
$$

5. Reardon

6. PASS theory (planning, attention, simultaneous, and successive processing)
مقدمه

نارسـاخوانى ' يكك اختلال عصــب تحولى 'رايج اسـت كه بر اثر تعامل

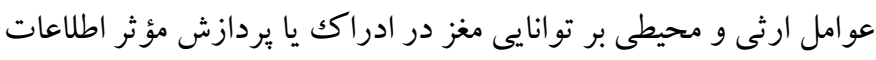

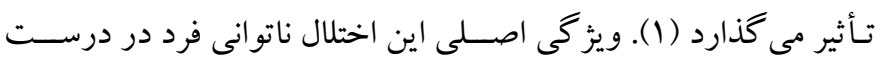

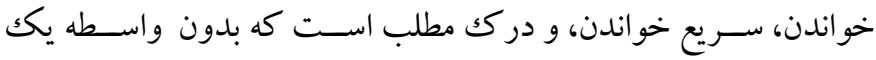

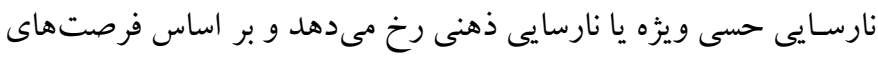

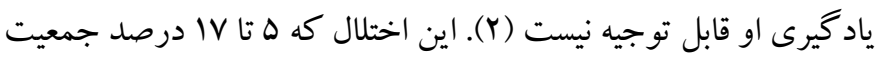

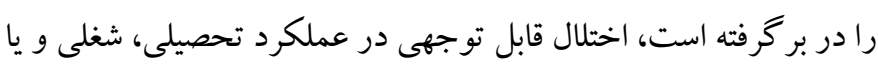
فعاليت هاى زندگى روزمره ايجاد مى كند (r).

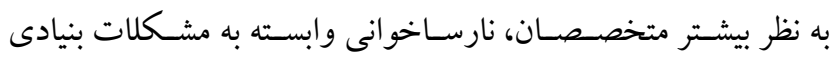
شـناختى است و شو اهد محكمى وجود دارد كه نشان مىدهد اين اختلال

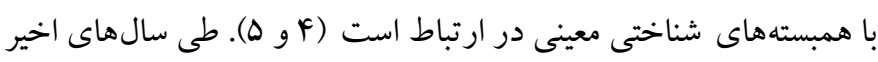

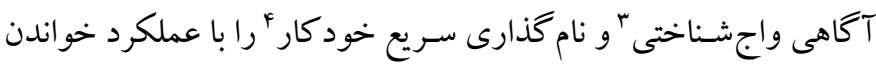
مرتبط دانستهاند و اين ارتباط در در كك نارساخوانى نيز اهميت يِيدا كرده

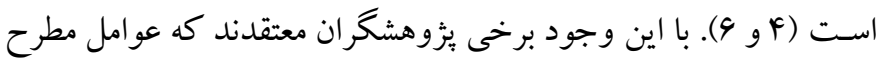

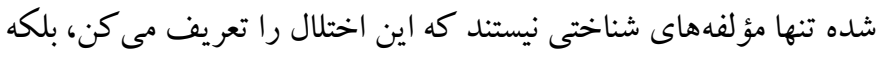
بررسى جامع اين ناتوانى نيازمند مطالعه بنيادى عوامل شـناختى در حيطه

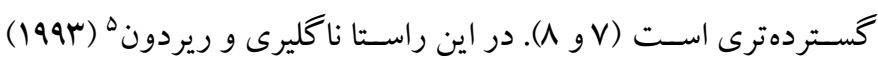

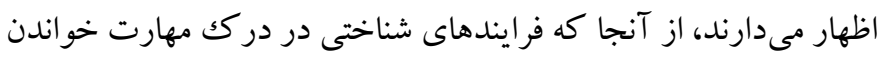
و به ويزه مشكلات خو اندن مفيد هستند، بايد براى فهم دقيق نارساخو انى إنى فراتر از آكاهى واجشسناختى و نام كذارى سـريع خود كار حر كت كرد و

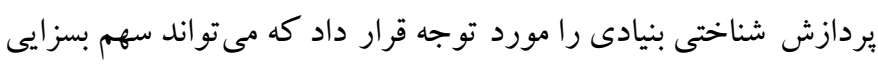

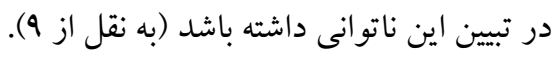

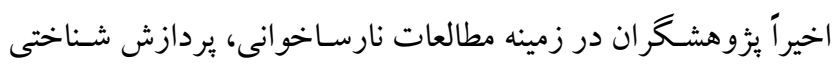
بنيادى را به عنوان يكك مفهوم جندبعدى در نظر گرفته (برخلاف ديد دماه

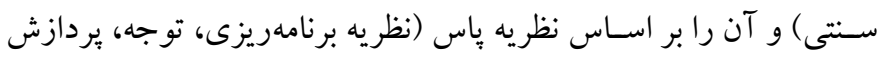

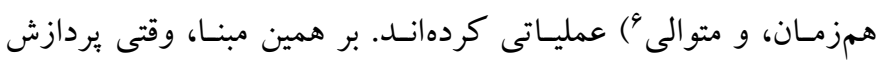

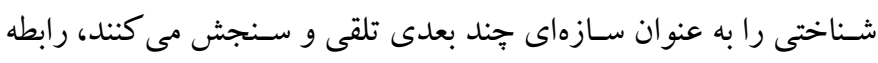

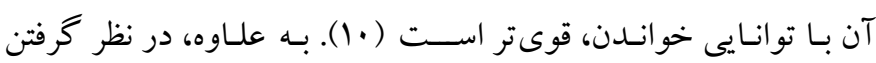

1. Dyslexia

2. Neurodevelopmental disorder

3. Phonological awareness

4. Rapid automatized naming (RAN) 
ياس در سـالهاى اخير سـهم عمدهاى در فعاليتهاى تشـخيصى و بالينى

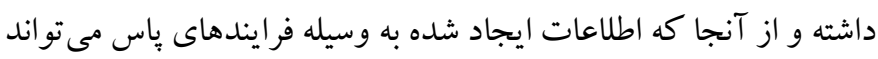

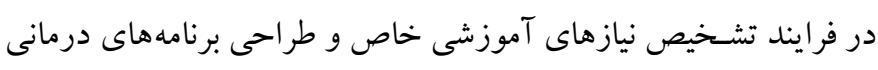

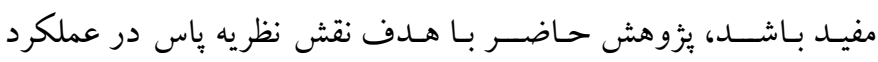

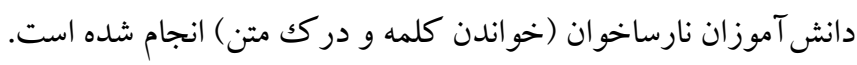

روش الف) طرح يزوهش و شر كت كنند كان: اين ئزوهش با توجه به ماهيت

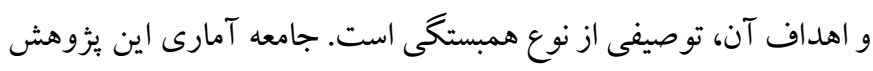

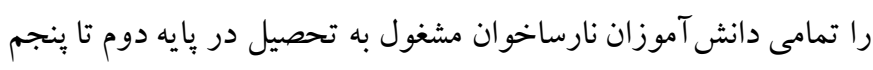

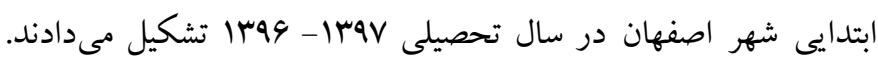

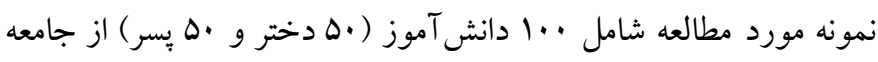
آمارى مذكور بود كه به روش تصادفى جندمرحلهاى، از ميان مناطق

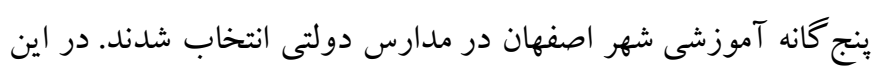

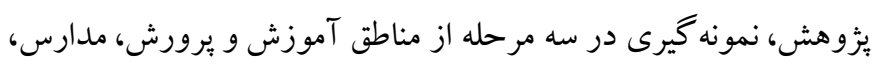

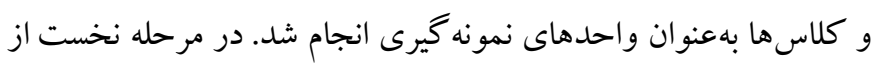

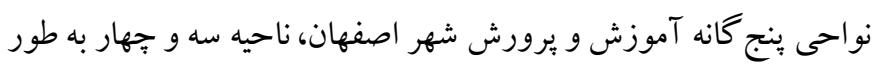
تصادفى انتخاب شدند؛ در مرحله دوم از بين مدارس ابتدايى دولتى

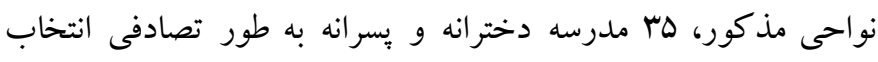

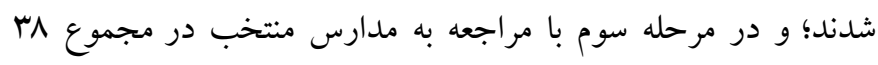

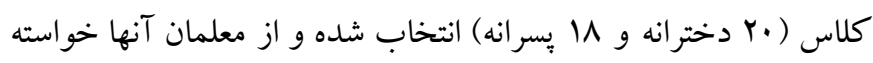

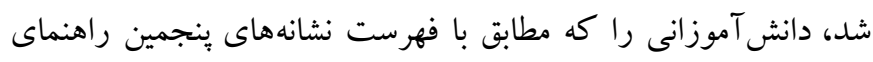

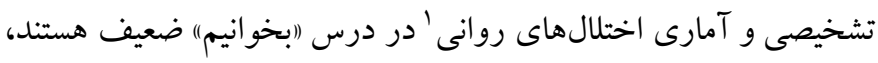

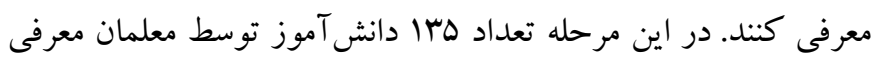

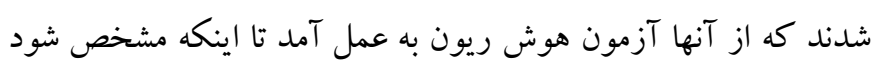

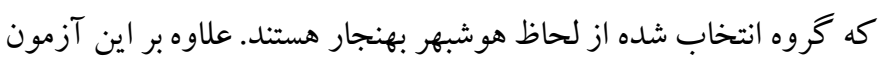
تشخيصى خواندن و نارساخو انى معرفى شده در بخش ابزار جهت احراز

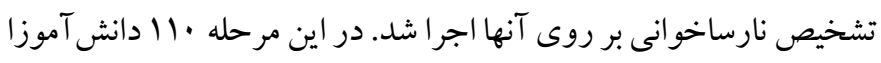

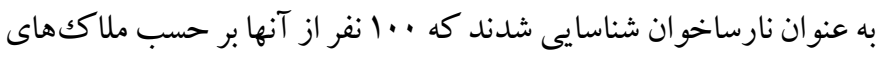

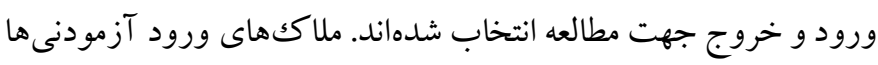
شامل دارا بودن هوشبهر متوسط، تشخيص نارساخوانى بر اساس آزمون
در سـالهاى اخير نتايج يزوهش هاى انجام شده بر حسب نظريه ياس

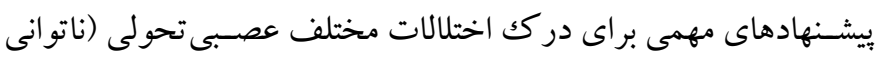

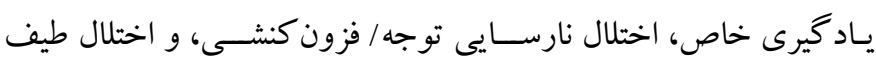

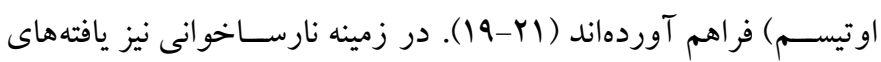

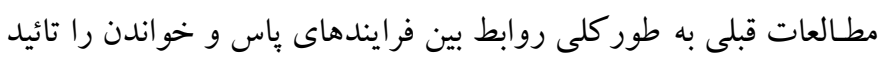

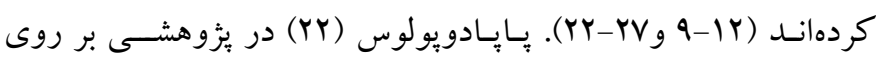

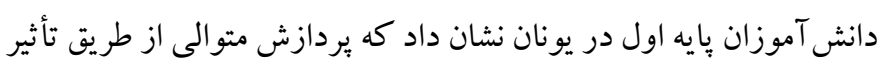

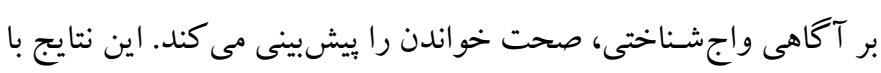
ديد كاه داس هماهنگك است كه شكست در خو اندن را رانتيجه نارسايى در

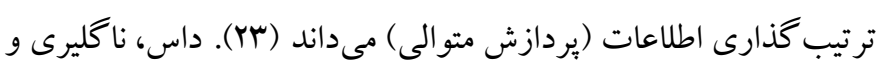

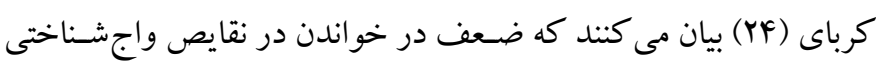

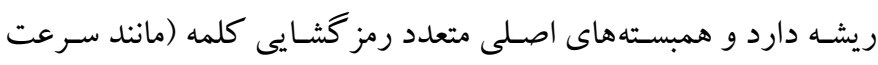

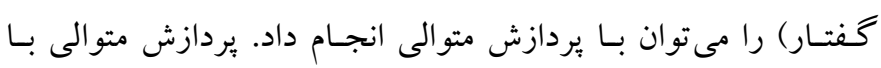

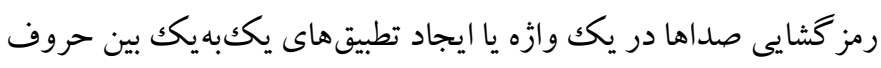

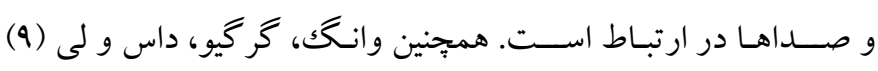

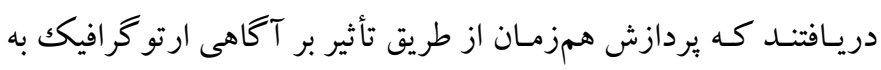

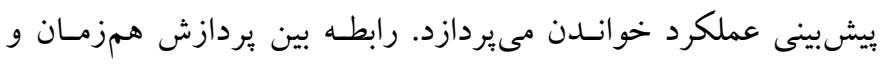

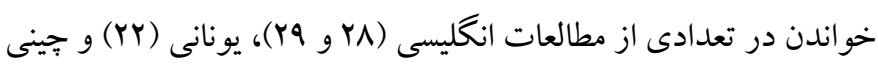

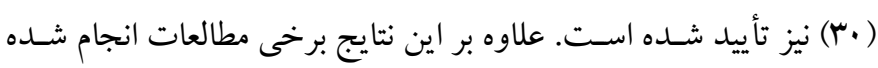

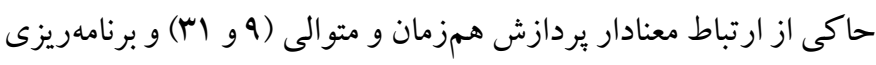

$$
\text { (9 و اسو (r ) با مقياس هاى در كك مطلب بودهه است. }
$$

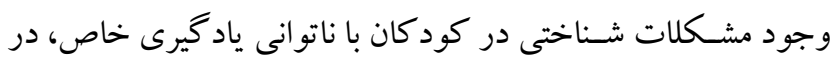

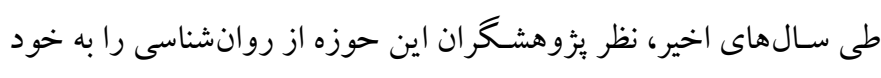

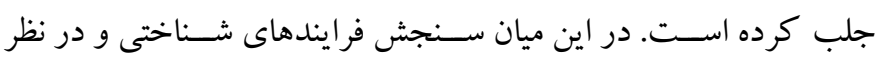

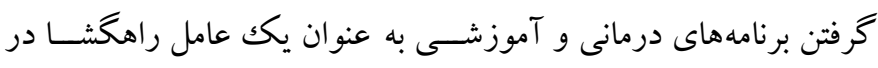

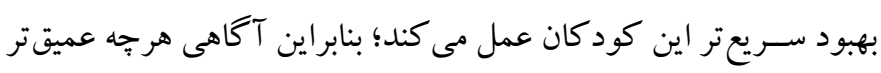

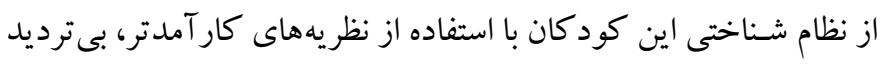

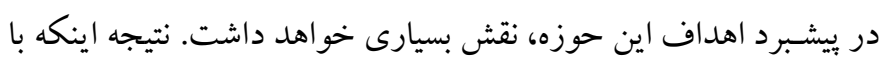

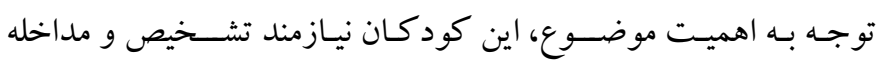

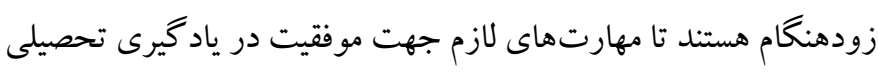
را فرا بخيرند. در راسـتاى مطالب مطرح شـــه و با توجه به اينكه نظريه

1. Diagnostic and statistical manual of mental disorders, fifth edition 
11 سـالكى به كار مىرود و از F خردهمقياس كدهاى برنامهريزى شده؟، توجه بيانى ه، ماتريس ها، و ارقام “ تشـكيل شــده اســت. فرم كو تاه نظام سـنش شناختى - وير ايش دوم توسط نا كليرى، داس و كلدشتاين (4)

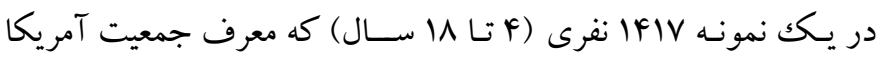
بودنـد، هنجاريابى شــده اســت. در اين مطالعه ضـــرايب اعتبار (آلفاى

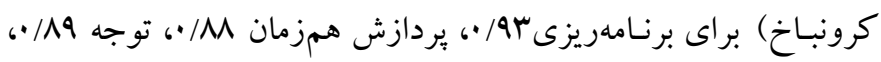

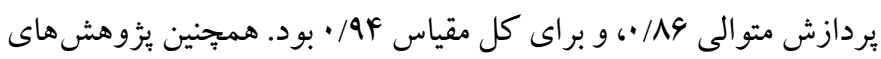
مرتبط بـا روايى بيشبين، ارتبـاط اين ابزار را بـا ويرايش ســوم آزمون

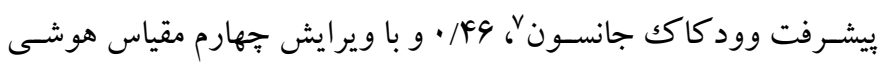
و كسـلر^، 99/ · به دسـت آوردند. جهت محاسـبه اعتبار فرم كو تاه نظام سـنجش شناختى - وير ايش دوم در جامعه ايرانى، اين ابزار روى نمونهاى مشـتمل بر ... انفر از دانش آموزان شـهر اصفهان اجرا شد و يس از آن ضرايب اعتبار به روش آلفاى كرونباخ براى خردهمقياسهاى اين ابزار در

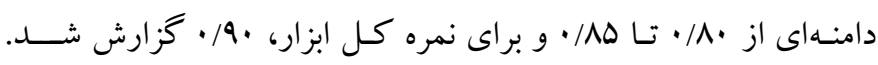

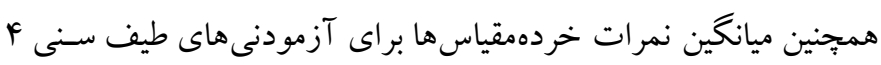
تا fl سـاله نشـان داد كه فرايندهاى شـناختى با سـن افزايش مىيابد و رشـد آن از يكك روند سـنى تبعيت مى كند. اين نتايج نشـان از رابطه بين عملكرد در مقياس هاى توانايى هاى شـناختى و سـن است كه جنبه مهمى

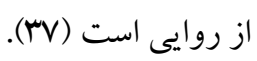

". آزمون خوانلدن و نارسـا ناخوانى (نما) ج؛ اين آزمون را كرمى نورى و

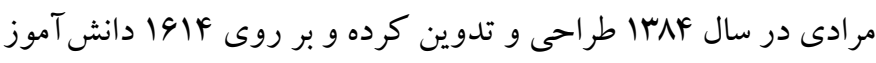

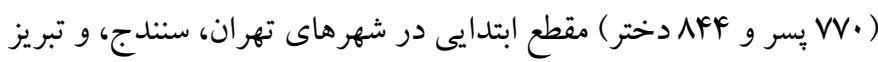
هنجـاريسابى كردنـد. آزمون خوانـدن و نارســاخوانى از · ا خردهمقياس تشـكيل شــده اسـت. خردهمقياسهاى به كار رفته در آزمون نما شـامل آزمون خوانسـن كلمـات، دركك خوانسدن متن، زنجيره كلمسات، دركك كلمـات، قـافيه، حذف آواها، خواندن كلمات بىمعنا، ناميدن تصــاوير، نشانه حروف، و نشانه كلمات است. هدف آزمون خواندن و نارساخوانى بررسى عملكرد خو اندن دانش آموزان بهنجار دختر و يسر با ويز گیىهاى دوزبانگیى و يك زبانكى و تشخيص كود كان داراى مشكلات نارساخوانى

\section{Digit}

7- Woodcock-Johnson III tests of achievement

8. Wechsler intelligence scale for children-fourth edition

9. Reading and dyslexia test (NEMA)
تشخيصى خواندن - نارساخوانى، و نداشتن اختلالهاى ديخر مانند

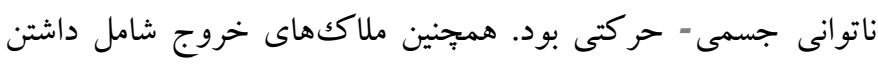
اختلالات هيجانى - رفتارى و عدم رضايت افراد نمونه و والدين آنها بوده.

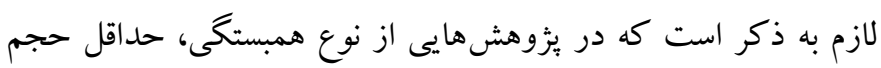

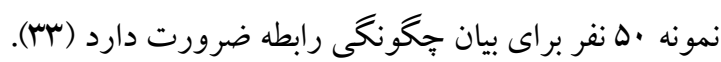

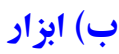

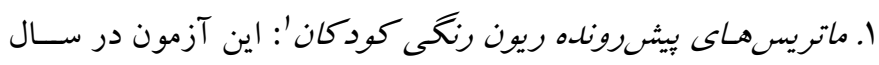

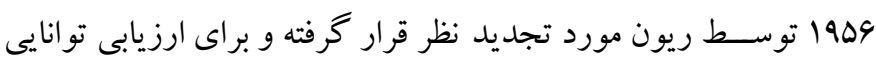

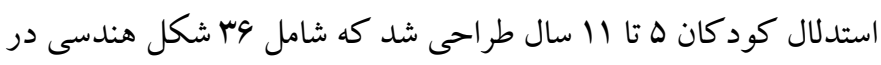
سـه مجموعه A, B, A. B است. نمره كذارى آزمون ريون كود كان به

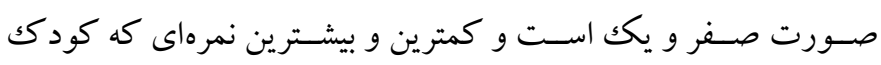

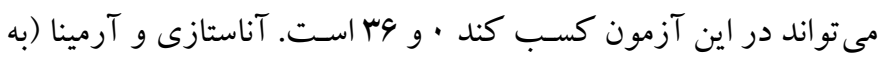

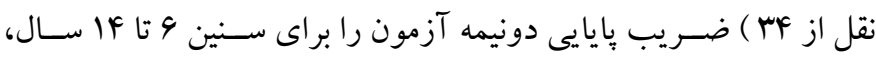

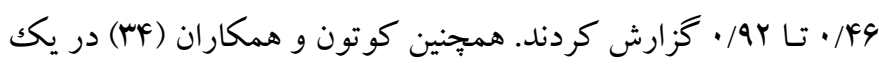

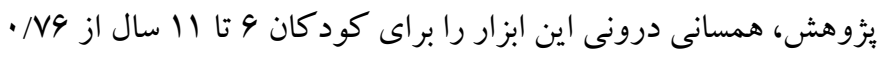

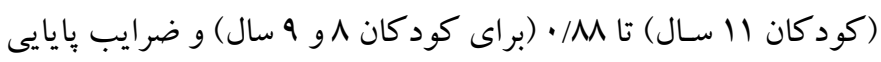

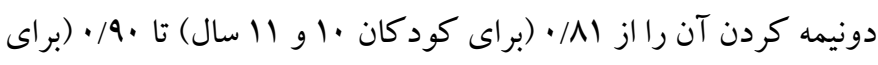

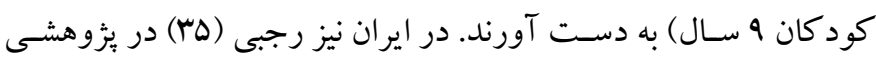

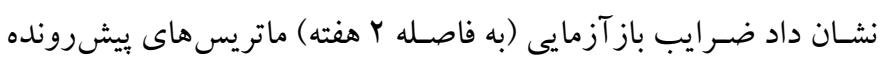

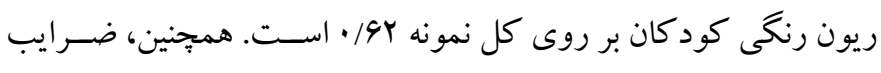

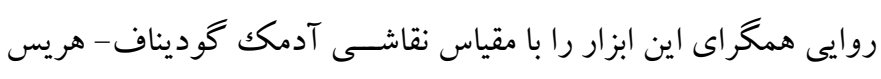

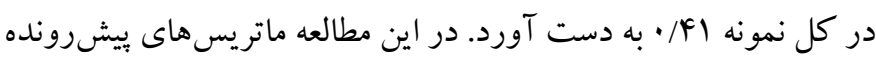
ريونبا هدف تشخص بهنجار بودن بودن يا نبودن دامنه هوشى افر اد نمونه اسـتفاده شـده اسـت تا مشـخص شـود مشكلات ياد گيرى آنان ناشى از

$$
\text { كمتوانى هوشى نيست. }
$$

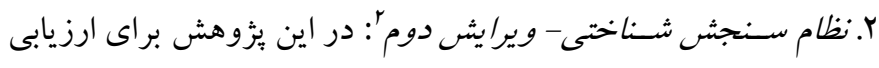

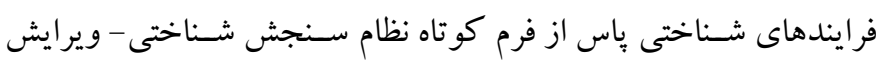

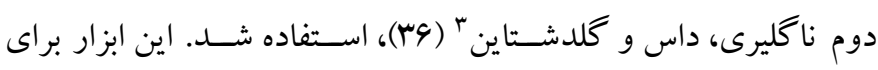

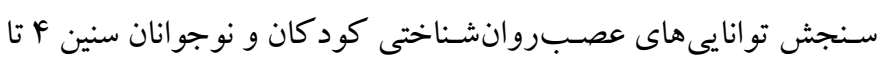

1. Raven's colored progressive matrices

2. Cognitive assessment system, second edition

3. Naglieri, Das, Goldstein

4. Planned codes

5. Expressive attention 
دانشـاه اصـفهان، به اداره آموزش و يرورش ناحيه باو F شـهر اصـفهان مراجعـه شـــه و مجوزهـاى لـازم جهـت انتخـاب افراد نمونسه و اجراى يرسشنامه ها و ابزارهاى مختلف، اخذ شد. سيس با توضيح هدف يثروهش و بـا تـأكيـد بر رعايت اصــول اخلاقى (احراز شــناســهـ اخلاق بزٔوهش: 1398.093 مانند رازدارى، نداشتن بار مالى، و اجبارى IR.UI.REC نبودن شــركت در بززوهش، رضــايت آزمودنى ها جلب شــد و به آنها اطمينـان داده شـــد كـه اكر در حين اجراى بثزوهش به هر دليلى از ادامه ليه

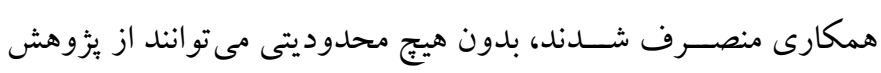
خارج شـوند. بعد از \& هفته تمامى اطلاعات جمع آورى و تجزيه و تحليل شد. لازم به ذكر است جهت تحليل دادهها علاوه بر شاخص هاى توصيفى از رگرسيون جندمتغيره استفاده شد.

\section{يافتهها}

به منظور بررسى نقش فرايندهاى شناختى ياس در تبيين توانيى خواندن كلمه و دركك متن در كود كان مبتلا به نارســاخوانى از ركرســيون جند متغيره كام به كام اسـتفاده شـد. در ادامه ابتدا، شـاخص هاى توصسيفى و

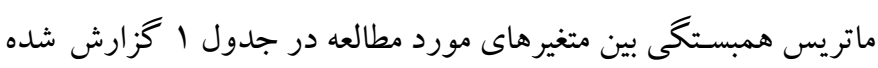

بود (Y^). روش اجرا و نمره گذارى آزمون خواندن و نارساخوانى به اين صورت است كه اين آزمون به صورت انفرادى اجرا مىشود. با توجه به

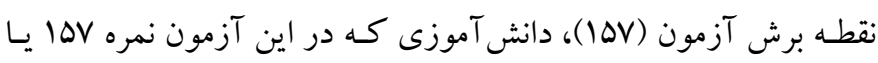

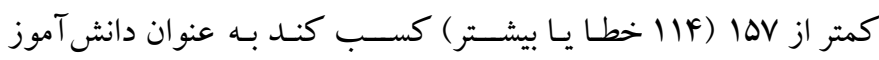
نارسـاخوان تشـخيص داده مىشـود. ياسخ هاى درست هر خردهمقياس با مراجعه به جدول ياسخخهاى صحيح، محاسبه مى شود و سيس با مر اجعه به جدول مربوطه، نمره تراز شــده به دسـت مى آيد. للازم به ذكر اســت كه نمرات تراز شـده براى هر يايه در هر شهرستان (تهران، تبريز، و سنندج)، متفاوت اسـت. ميزان همسـانى درونى آزمون خواندن و نارسـاخوانى نيز

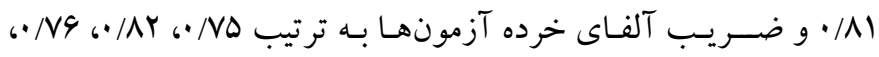

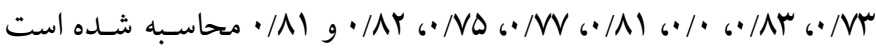
(Y^). همجينين نتايج تحليل عاملى اكتشافى روى خردهمقياسهاى آزمون

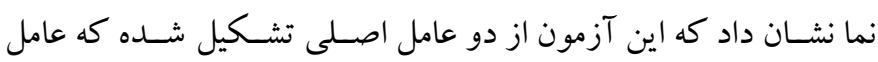
نخستـ به ترتيب شـامل آزمونهاى لغات با بسـامد بالا، متوسـط، درك كـ كلمـات، حـذف آواهـا، خواندن ناكلمات، و شــبه كلمات؛ و عامل دوم شــامل آزمونهاى زنجيره كلمات، قافيه، ناميدن تصـاوير، درك متن، و

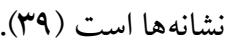
ج) روش اجرا : ابتـدا بـا تصــويـبـ برويوزال اين بثزوهش در تـاريخ 

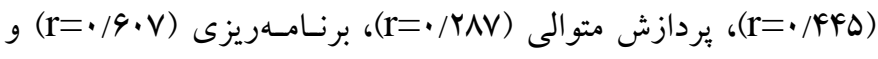

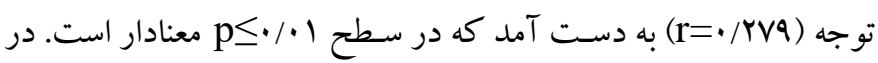
ضــمن بين خواندن كلمه با برنامهريزى رابطه معنادارى به دسـت نيامده
با توجه نايج جدول ا ، ضـرايب همبسـتِى محاسبه شده بين خواندن

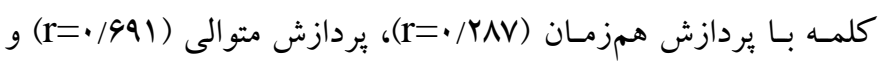

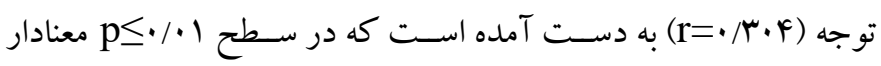
اسـت. ضر ايب همبستكى محاسبه شده بين دركك متن با بردازش همزمان 
معنادارى نداشـتند و از معادله حذف شدند. در ارتباط با بيش بينى درك متن، در گَام نخســت برنـامهريزى و در كام دوم برنامهريزى و يردازش

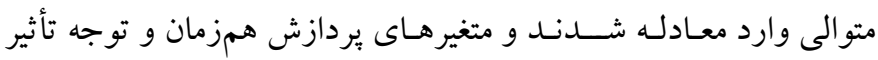

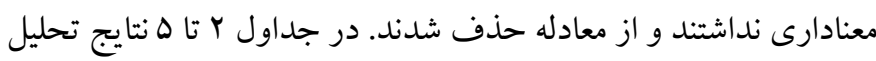

$$
\text { ركرسيون گزارش شده است. }
$$

به منظور بررسى دقيقتر روابط مذكور و همجنين بررسى قدرت

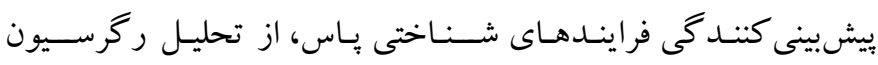

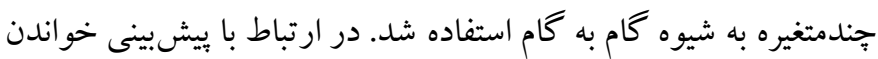

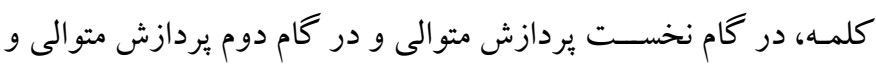

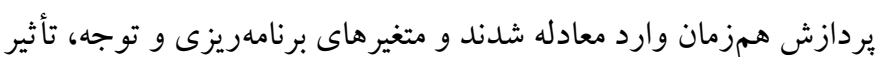

جدول ז: خلاصه مدل ركرسيون، تحليل واريانس و مشخصهاى آمارى ركرسيون خواندن كلمه بر فرايندهاى باس

\begin{tabular}{|c|c|c|c|c|c|c|c|c|c|}
\hline S.E & $\mathbf{R}^{2}$ & $\mathbf{R}$ & $\mathbf{P}$ & $\mathbf{F}$ & ميانكين مجموع مجذورات & Df & مجموع مجذورات & & كام \\
\hline \multirow{2}{*}{ IF/NAD } & \multirow{2}{*}{$\cdot / 4 \mathrm{VI}$} & \multirow{2}{*}{.$/ 991$} & \multirow{2}{*}{$\cdot \cdots \cdot$} & \multirow{2}{*}{$19 / 919$} & $19091 / 91$. & 1 & $19 \Delta 91 / 91$. & رخرسيون & \multirow{2}{*}{1} \\
\hline & & & & & rIN/9.9 & 91 & rifrt/v. & باقيمانده & \\
\hline \multirow{2}{*}{$19 / \Delta 99$} & \multirow{2}{*}{$\cdot / 491$} & \multirow{2}{*}{$\cdot N \cdot 9$} & \multirow{2}{*}{$\% \cdots 1$} & \multirow{2}{*}{ FN/IFV } & 1.r/g/TQA & r & r. FrT/VQG & رگرسيون & \multirow{2}{*}{ r } \\
\hline & & & & & $Y|r /| q \mid$ & qv & $r \cdot \Delta A Y / \Delta I F$ & باقيمانده & \\
\hline
\end{tabular}

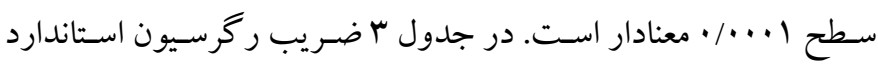

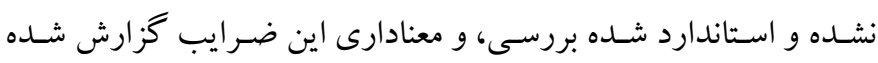

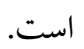

بر اساس نتايج جدول Y مى توان گفت كه بردازش متوالى و همزمان

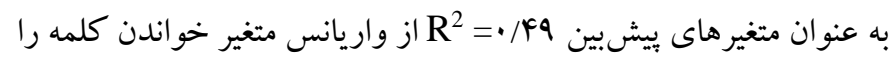

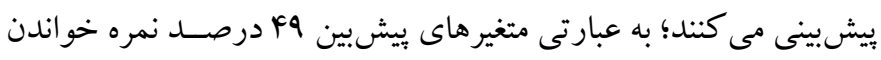

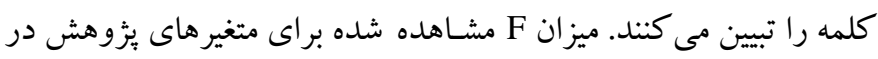

جدول Гّ: ضرايب ركرسيون كام به كام خواندن كلمه روى متثيرهاى بيشبين

\begin{tabular}{|c|c|c|c|c|c|c|}
\hline معنادارى & $\mathbf{T}$ & B & خطاى استاندارد bار & B & شاخصها & كام \\
\hline.$\cdots 1$ & $9 / 9 \mathrm{WV}$ & .1991 & ./AYV & $F / \cdot F r$ & يردازش متوالى & 1 \\
\hline.$\cdots 1$ & ^/৭९৯ & .199. &.$/ 4 r$. & r/A9. & يردازش متوالى & \multirow{2}{*}{ r } \\
\hline.$/ \% q$ & $1 / 991$ &.$/ N \mathrm{~F}$ & $\cdot / r \cdot r$ & $\cdot / F \cdot F$ & برد دازش همزمان & \\
\hline
\end{tabular}

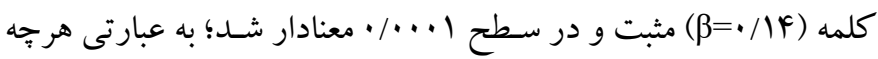

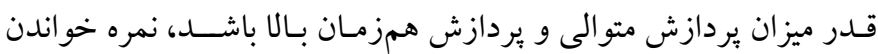

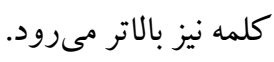

بـاتوجـه بـه نتـايج جـدول س، در كام نخســت اثر بردازش متو الى بر

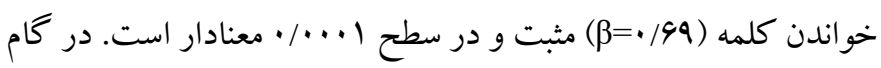

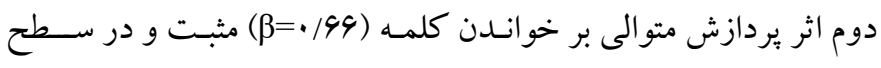

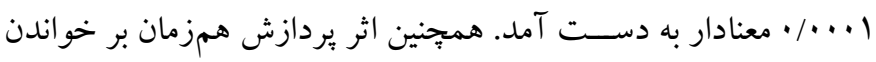


جدول ع: خلاصه مدل ركرسيون، تحليل واريانس و مشخصههاى آمارى ركرسيون دركى متن بر فرايندهاى پاس

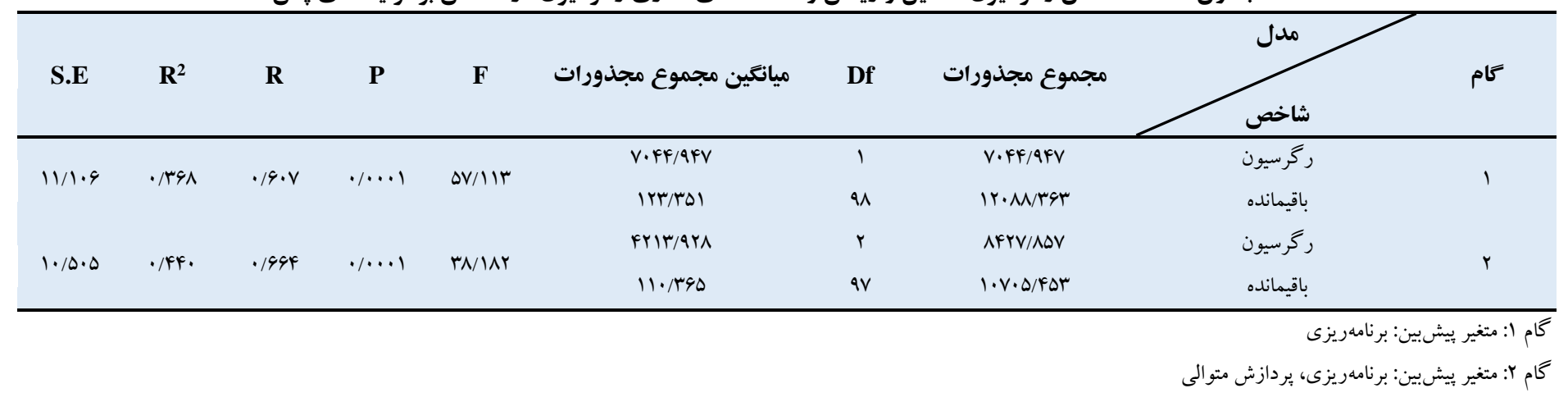

متن را تبيين مى كنند. ميزان F مشاهده شده براى متغيرهاى يثزوهش در سطح 1 +. • • معنادار است. در جدول ه ضريب ركرسيون استاندارد نشده و استاندارد شده بررسى، و معنى دارى اين ضرايب گزارش شده است.
بر اساس نتايج جدول \& مى توان كفت كه برنامهريزى و يردازش

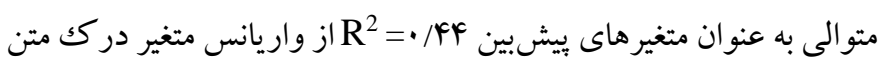

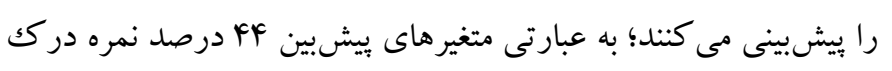

جدول 0: :ضرايب ركرسيون تام به كام دركى متن روى متغيرهاى ييشيين

\begin{tabular}{|c|c|c|c|c|c|c|}
\hline معنادارى & $\mathbf{T}$ & B & خطاى استاندارد b & B & & كام \\
\hline$\cdot / \cdots 1$ & $V / \Delta \Delta V$ & $\cdot 19 \cdot V$ & $\cdot 1 \cdot \mathrm{V} 9$ & $\cdot$ / DVG & برنامهريزى & 1 \\
\hline$\cdot 1 \cdots 1$ & $\mathrm{~V} / \mathrm{AVV}$ & .1999 & $\cdot / \cdot V r$ & $\cdot / \Delta 9 \Lambda$ & برنامهريزى & \multirow[t]{2}{*}{ r } \\
\hline$\cdot / \cdots 1$ & $r / \Delta F$. & $\cdot / r 99$ & (r/r. & $1 / \cdot V F$ & يردازش متو الى & \\
\hline
\end{tabular}

ريزى" هســـنـــ بـهـ عبارت ديخر، عملكرد "خواندن كلمه" بر اســاس

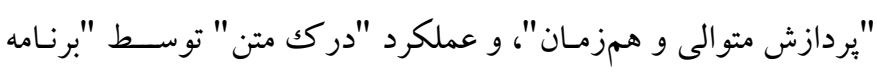

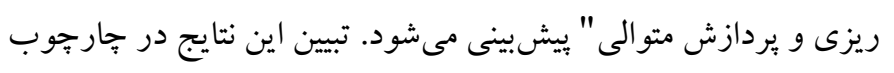

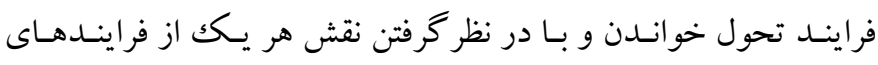
شناختى پياس در عملكرد خواندن، امكانيذير است.

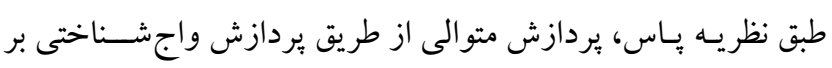

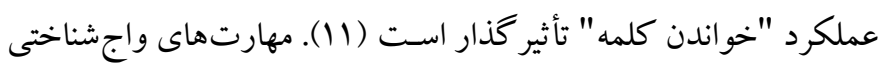
در خواندن اوليه سـهم مهمى دارند و عنوان شـده اسـت كه اين شـرايط (نقايص واجشـاختى)، دليل اصـلى نارساخوانى در كود كان است (1))، اما برخى متخصسصـان معتقدند كه زيربناى نقايص واجشناختى، مشكلات خاص در يردازش متوالى اسـت كه منجر به اختلال در خواندن مىشــود

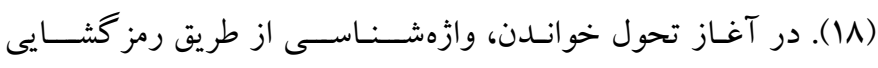
صــاشـناختى حاصـل مى شـود كه شـامل شـناسـايى حروف جداكانه در وازهها، بازيابى صداهاى متناظر آنها، ذخيره صداها در حافظه كوتاهمدت،
بـا توجه به نتايج جدول ه، در كام نخسـت اثر برنامهريزى بر درك

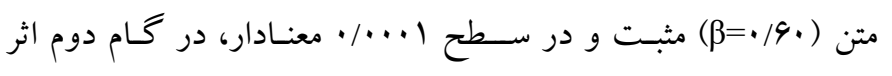

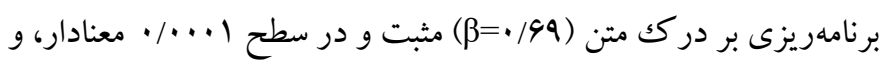
همجنين اثر يردازش متوالى بر خواندن كلمه (Y4/. •=

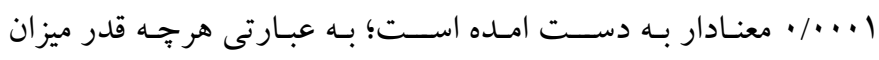
برنـامـهريزى و يردازش متوالى بـالـا باشــد، نمره خواندن كلمه نيز بالاتر

\section{بحث و نتيجه Fيرى}

يثزه حاضسر با هدف بررسسى نقش فرايندهاى شـناختى ياس در تبيين عملكرد "خواندن كلمه" و "دركك متن " كود كان نارسـاخوان انجام شد.

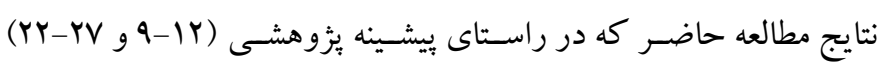
است، اين فرضيه را تأييد مى كند كه كود كان نارساخوان، داراى عملكرد مرتبط بـا كاركرد ناقص در "يردازش همزمان، يردازش متوالى، و برنامه 
مهمى از خو اندن محسوب مى شود (11). همجنين، در كك مطلب نيازمند

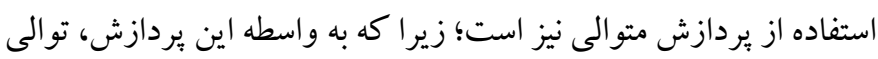

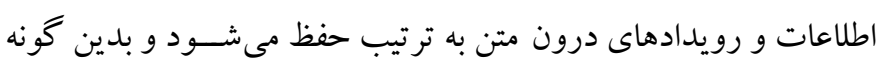

$$
\text { معناى متن، استخر اج و استباط مى شود (YV). }
$$

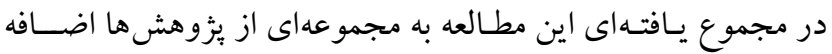

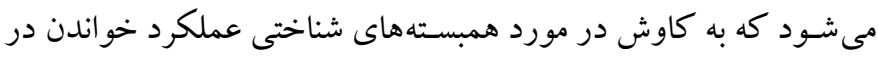

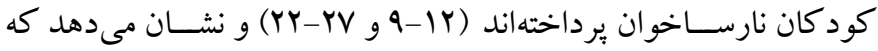

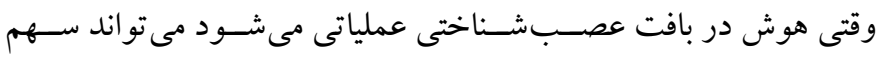

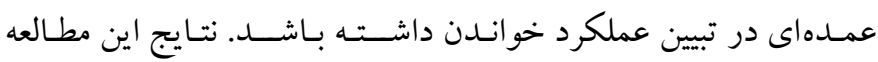

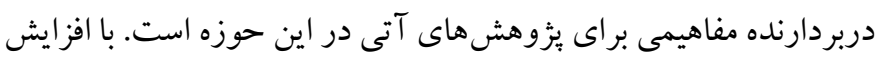

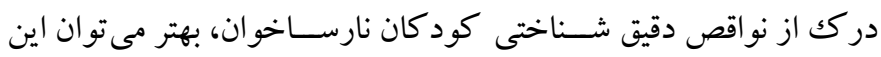

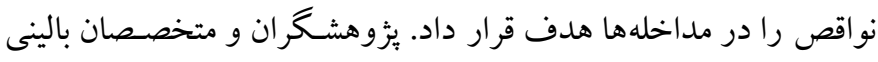

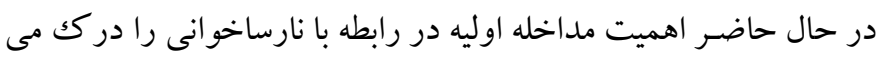

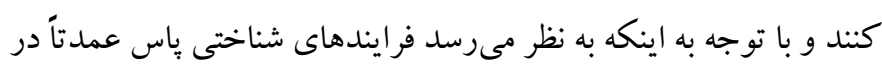

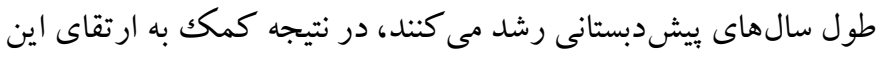

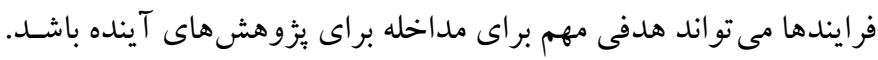

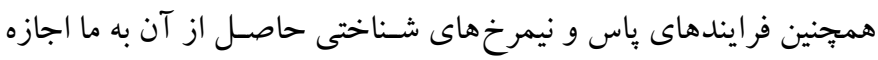

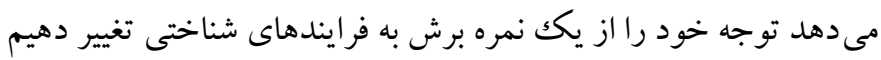

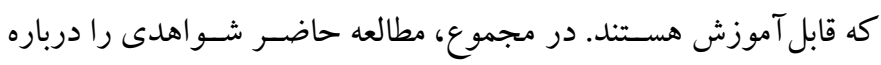

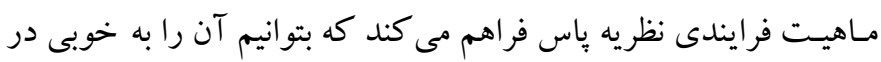
جهار هوب جامع ارزيابى عصب روانشـناختى قرار دهيم. همجنين نتايج

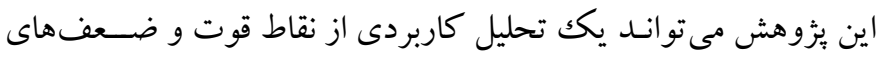
شـناختى در اختيار روانشـناسان قرار دهد و مسيرى را به سمت اصلاح و ورد طراحى مداخلات خواندن فراهم كند.

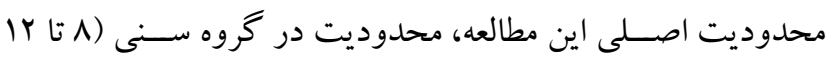
سال) و نوع اختلال ياد گيرى خاص (فقط اختلال خواندن) بوده است؛ به

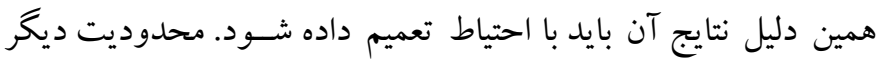

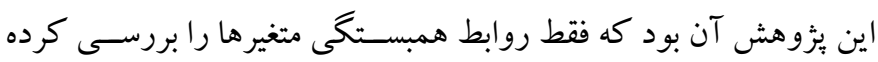

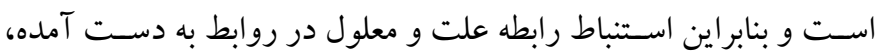

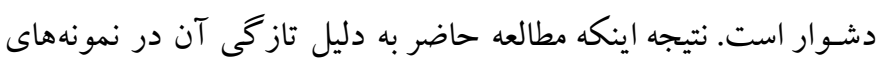

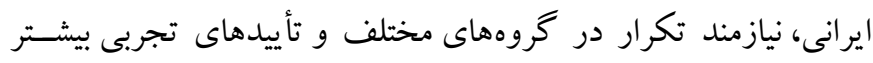

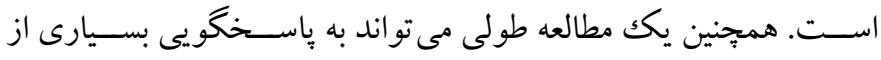

و تركيب صـداها به ترتيب سريالى (يشت سرهم) مىشود كه اين مر احل

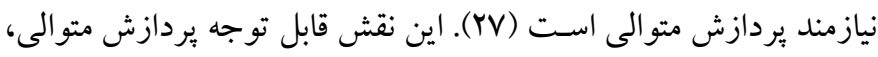

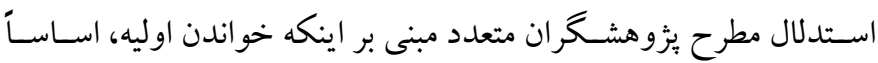

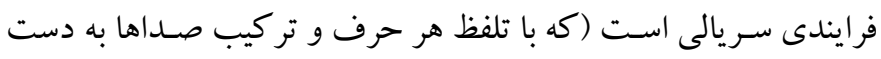

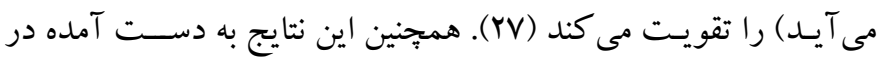

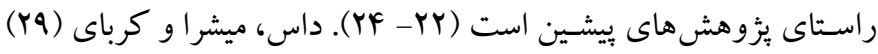

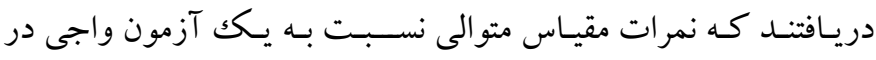

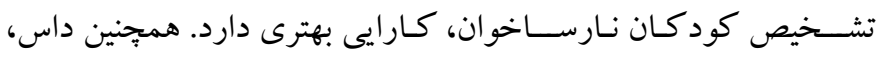

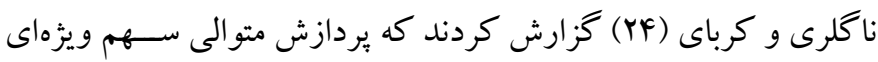

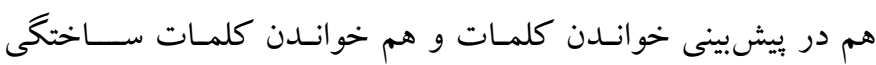

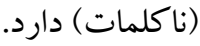

بـايد توجه داشـت كه بردازش همزمان نيز تأثيرات خود را بر روى

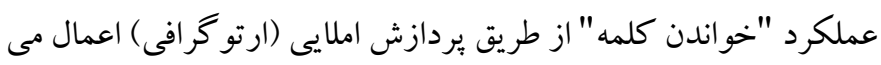

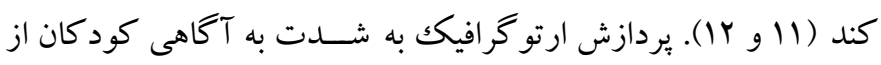

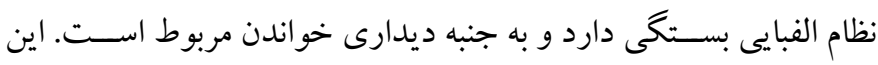

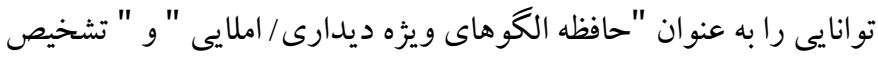
سـريع وازههاى جشـمى " تعريف كردهاند (11). در حالى كه كود كك در خواندن مهارت بيشـترى كسـب مى كند، تسـلط در خو اندن با شــناخت

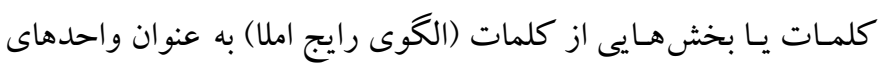

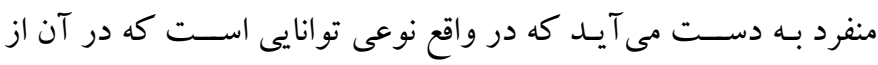

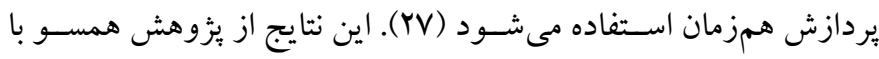

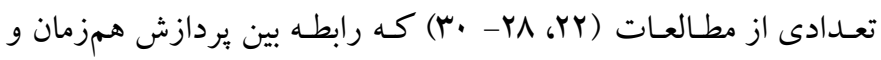
خواندن را تأييد كردهاند. هـدف نهايى خوانـدن، يعنى درك مطلـب، نيز نيـازمند اســفاده از

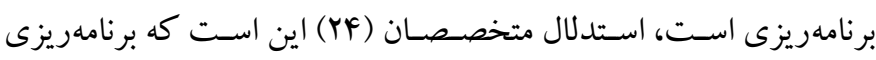
نقشى ثانويه را ايفا مى كند و به فرد تو انايى گسترش مهارت هاى شناختى

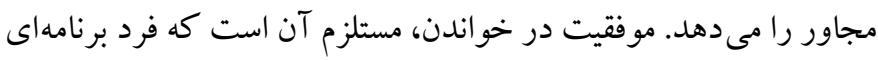

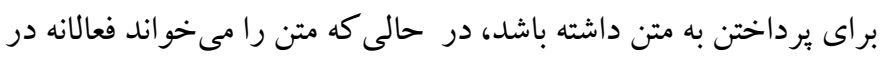

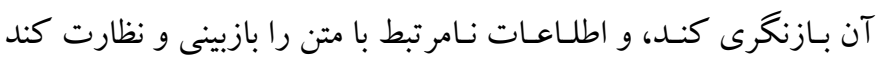

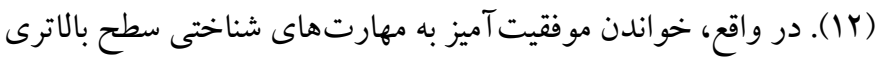

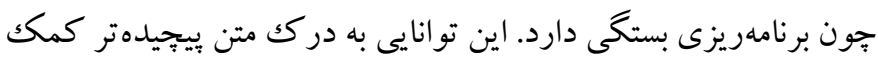

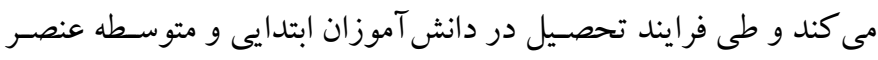


اصفهان با شـناسه اخلاق IR.UI.REC.1398.093 اسـت كه مجوز اجراى

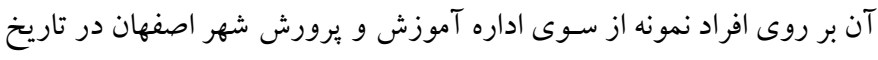

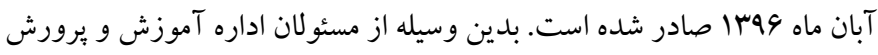

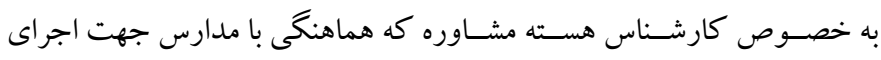
يُزوهش را انجام دادند و همجنين از كادر ادارى و مربيان مدارس و افراد نمونه

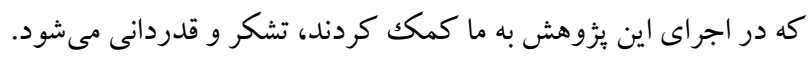
تضاد منافع: اين يُزوهش براى نويسند كان هيج گَونه تضاد منافع به دنبال نداشته است.
ســؤالات در اين حوزه كمكك كند. با توجه به اينكه يافتههاى حاصسل از

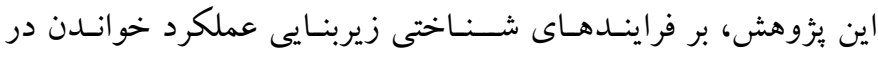

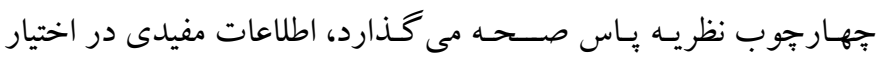

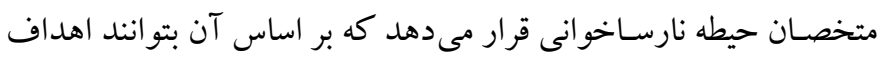
برنامه هاى مداخلهاى را به سمت اصلاح و بهبود اين فرايندها، تغيير دهند.

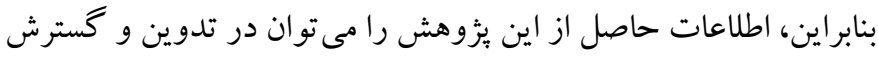
برنامه هاى توانبخشى ياسمحور، مورد استفاده قرار داد. تشكر و قدردانى: مطالعه حاضر بر گرفته از رساله مقطع دكتراى خانم مريم صـمدى در رشـته روانشـناسى و آموزش كود كان با نيازهاى خاص دانشئهاه 


\section{References}

1. American Psychiatric Association. Diagnostic and statistical manual of mental disorders .5th ed. Washington, DC: American Psychiatric Association; 2013. pp: 66-74. [Link]

2. Layes S, Lalonde R, Mecheri S, Rebaï M. Phonological and cognitive reading related skills as predictors of word reading and reading comprehension among Arabic dyslexic children. Psychology. 2015; 6 (1):2038. [Link]

3. Morken F, Helland T, Hugdahl K, Specht K. Reading in dyslexia across literacy development: A longitudinal study of effective connectivity. Neuroimage. 2017; 144: 92-100.[Link]

4. Wang LC, Liu D, Chung KK, Yang HM. Development of lexical tone awareness in Chinese children with and without dyslexia. Contemp Educ Psychol. 2017; 49: 203-214. [Link]

5. Reynolds C R, French C L. The brain as a dynamic organ of information processing and learning. In Handbook of school neuropsychology. Hoboken, NJ: John Wiley \& Sons, Inc. 2005. pp: 86-119. [Link]

6. Kirby JR, Parrila RK, Pfeiffer SL. Naming speed and phonological awareness as predictors of reading development. J Educ Psychol. 2003; 95 (3):453-464. [Link]

7. Boets B, Wouter s J, Van Wieringen A, Ghesquiere P. Auditory processing, speech perception and phonological ability in pre-school children at high-risk for dyslexia: A longitudinal study of the auditory temporal processing theory. Neuropsychologia. 2007; 45 (8):1608-1620. [Link]

8. Chung KK, Ho CS, Chan DW, Tsang SM, Lee SH. Cognitive profiles of Chinese adolescents with dyslexia. Dyslexia. 2010; 16 (1):2-23. [Link]

9. Wang X, Georgiou GK, Das JP, Li Q. Cognitive processing skills and developmental dyslexia in Chinese. J Learn Disabil. 2012; 45 (6):526-537. [Link]

10. Georgiou GK, Das JP. Reading comprehension in university students: Relevance of PASS theory of intelligence. J Res Read. 2014; 37 (S1):S101-115 [Link]

11. Kendeou P, Papadopoulos TC, Spanoudis G. Reading comprehension and PASS theory. In: Cognition, intelligence, and achievement: A tribute to JP Das. Elsevier Academic Press. 2015. pp: 117-136. [Link]

12. Dunn K, Georgiou GK, Das JP. The PASS to superior reading performance. High Ability Studies. 2018; 29 (2):135-148. [Link]
13. Naglieri JA, Otero TM. Essentials of CAS2 assessment. New York, NY: John Wiley \& Sons; 2017.pp: 1-47. [Link]

14. McInnes A, Humphries T, Hogg-Johnson S, Tannock R. Listening Comprehension and Working Memory Are Impaired in Attention-Deficit Hyperactivity Disorder Irrespective of Language Impairment. J Abnorm Child Psychol. 2003; 31 (4): 427-43. [Link]

15. Kendeou P, Van Den Broek P, Helder A, Karlsson J. A cognitive view of reading comprehension: Implications for reading difficulties. Learning disabilities research \& practice. 2014; 29 (1):10-6. [Link]

16. Das JP. Three Faces of Cognitive Processes: Theory, Assessment, and Intervention. In: Cognition, intelligence, and achievement: A tribute to JP Das. Elsevier Academic Press. 2015. pp: 19-47. [Link]

17. Das JP, Misra SB. Cognitive planning and executive functions: Applications in management and education. New Delhi: SAGE Publications. 2014; 3-19. [Link]

18. Naglieri JA, Otero TM. Redefining intelligence with the planning, attention, simultaneous, and successive theory of neurocognitive processes. In Contemporary intellectual assessment: Theories, tests, and issues (4th Ed.). New York, NY: Guilford Press, 2018. pp: 195218. [Link]

19. Taddei S, Contena B. Cognitive processes in ADHD and Asperger's disorder: Overlaps and differences in PASS profiles. J Atten Disord. 2017; 21 (13): 10871093. [Link]

20. Iglesias-Sarmiento V, Deaño M, Alfonso S, Conde Á. Mathematical learning disabilities and attention deficit and/or hyperactivity disorder: A study of the cognitive processes involved in arithmetic problem solving. Res Dev Disabil. 2017; 61: 44-54. [Link]

21. samadi M, Ghamarani A, Faramazi S. Applicability of the Theory of PASS in Predicting Math Performance of Students with Special Learning Disabilities. JOEC. 2019; 18 (3):65-76. [In Persian]. [Link]

22. Papadopoulos, T.C. Phonological and cognitive correlates of word-reading acquisition under two different instructional approaches in Greek. Eur $\mathbf{J}$ Psychol Educ. 2001; 16 (4):549-568. [Link]

23. Das J.P. Reading Difficulties and Dyslexia: An Interpretation for Teachers. New Delhi: SAGE Publications, 2009. pp: 29-46. [Link]

24. Das JP, Naglieri JA, Kirby JR. Assessment of cognitive processes: The PASS theory of intelligence. Boston: Allyn \& Bacon; 1994. [Link] 
25. Naglieri JA, Otero T, DeLauder B, Matto H. Bilingual Hispanic children's performance on the English and Spanish versions of the Cognitive Assessment System. Sch Psychol Q. 2007; 22 (3):432-448. [Link]

26. Das JP, Janzen T, Georgiou GK. Correlates of Canadian native children's reading performance: From cognitive styles to cognitive processes. J Sch Psychol. 2007; 45 (6): 589-602. [Link]

27. Georgiou GK, Manolitsis G, Tziraki N. Is intelligence relevant in reading " $\mu \alpha v^{\prime} \alpha$ " and in calculating " $3+5$ "? In: Cognition, intelligence, and achievement: A tribute to JP Das. Elsevier Academic Press. 2015. pp: 225243. [Link]

28. Das JP, Georgiou G, Janzen T. Influence of distal and proximal cognitive processes on word reading. Reading Psychology. 2008; 29 (4): 366-393.[Link]

29. Das JP, Mishra RK, Kirby JR. Cognitive patterns of children with dyslexia: A comparison between groups with high and average nonverbal intelligence. J Learn Disabil. 1994; 27 (4): 235-242. [Link]

30. Wang X, Georgiou GK, Das JP. Examining the effects of PASS cognitive processes on Chinese reading accuracy and fluency. Learn Individ Differ. 2012; 22 (1): 139-143. [Link]

31. Dunn K, Georgiou G, Das JP. The relationship of cognitive processes with reading and mathematics achievement in intellectually gifted children. Roeper Review. 2020; 42 (2):126-135. [Link]

32. Das JP, Georgiou GK. Levels of planning predict different reading comprehension outcomes. Learn Individ Differ. 2016; 48:24-28. [Link]
33. Delavar A. Educational and psychological research. Tehran: Virayesh Press; 2007. pp: 90-100. [Persian]

34. Cotton SM, Kiely PM, Crewther DP, Thomson B, Laycock R, Crewther SG. A normative and reliability study for the Raven's Coloured Progressive Matrices for primary school aged children from Victoria, Australia. Pers Individ Dif. 2005; 39 (3): 647-659. [Link]

35. Rajabi G. Normalizing the Raven colure progressive matrices test on students of city Ahvaz. Contemporary Psychology. 2008; 3 (1): 23-32. [In Persian] [Link]

36. Naglieri JA, Das JP, Goldstein S. Cognitive assessment system-Second edition: Brief. Austin, TX: Pro-Ed; 2014. [Link]

37. Samadi M, Ghamarani A, Faramazi S. The Study of Psychometric Characteristics of Cognitive Assessment System, Second Edition-Brief in Isfahan. Journal of Applied Psychology Research (in Press). [In Persian].

38. Kormi-Nouri R, Moradi A. Design study of reading and dyslexia in bilingual and monolingual children. Tehran: Organization for Educational research and planning. 2006. [In Persian].

39. Moradi A, Hosaini M, Kormi Nouri R, Hassani J, Parhoon $\mathrm{H}$. Reliability and validity of reading and dyslexia test (NEMA). Advances in Cognitive Science. 2016; 18 (1):22-34. [In Persian]. [Link] 